\title{
Analysis of Kharkai River Pollution around Adityapur: Causes and Impacts
}

\author{
Meenu Verma ${ }^{1}$, Manoj Ranjan Sinha ${ }^{2}$ \\ Kolhan University, Chaibasa
}

\begin{abstract}
Various causes are responsible for polluting water. Some natural causes are mixture of biodegraded portion of animal and plants to pure water, siltation by erosion of river banks etc. Domestic wastes and industrial wastes are manmade pollutants of water. The state of surface and ground water pollution in Jamshedpur is alarming. Especially the Kharkai is largely polluted by the people of Adityapur and Jamshedpur city. Necessity of water for each and every living being needs no description. They intake water directly or indirectly form physiological activities. If this in taking water is polluted, it will do harm that is for sure. Excess of pollution in the Kharkai river water leads to algal blooms. The worst part is, this bad impact transports to others through food chain. Therefore, we must be aware of the adverse influence polluted water may have on us. At present, we cannot prevent water being polluted cent percent, but minimization is very much needed. It is time we took some steps to start working on it.
\end{abstract}

Keywords: Kharkai, pollutants, domestic \& industrial waste, algal bloom

\section{Introduction}

\begin{abstract}
About the Kharkai
The Kharkai is derived from the Sanskrit word "Kharkaya" meaning "fast flowing river". The valley of the lower Kharkai is quite wide and rice is the primary crop. The Kharkai Dam is located at Ichha, Orissa. The Kharkai River is a river in eastern India. It originates from Mayurbhanj district, Orissa, on the north slopes of Darbarmela Parbat and the western slopes of Tungru Pahar of the Simlipal Massif. It flows past Rairangpur and heads north to about Saraikela and then east, entering the Subarnarekha in northwestern Jamshedpur at Domuhani, passing through Adityapur. It is one of the major tributaries of the Subarnarekha River. After entering Jharkhand its tributaries include the Torlo and Lli Gara on the left. Its last major tributary is the Sanjay, entering from the left, $17 \mathrm{~km}$ as the river flows above its mouth. There is a steel plant at Jamshedpur and many industries in Adityapur Industrial Area. The river gets polluted throughout its journey.
\end{abstract}

\section{Objectives of the study}

i. To identify the causes of water pollution of Kharkai river ii. To know the States of water pollution of Kharkai river iii. To know impacts of water pollution of Kharkai river iv. To find out a way to mitigate the water pollution of Kharkai river.

\section{Review of Literature}

Gautam in the year 1990 stated that Water, the universal solvent because of high dielectric constant has the property of dissolving most of the substances but the access of these substances lead to water pollution. [13]. Different aspects of water and waste water have been studied by many workers such as physicochemical characteristics of sewage entering into the river[5,7,9,8,12,15] The Physical factors contributing the great role in water quality such as Temperature, $\mathrm{pH}$ and Turbidity water level and intensity of illumination is also an important factor to maintain the water quality $[1,2,3,19]$. Sinha \& Das (1993) studied the effects of organic waste on macrozoobenthos in Ganga at Patna (Bihar) during the years 1984 \& 1985. The distribution and abundance of 5 groups of benthos viz., Polychaeta, Oligochaeta, Insecta, Gastropoda and Pelecypoda and Correlated the population with the Physico-Chemical parameters such as temperature, $\mathrm{pH}$, DO, BOD, COD, Chloride, Sulphate. Their studies revealed that at the entry point of Ganga at Patna near Digha a diverse group of organisms were present with a maximum diversity index of 1.9. As the river passes along the city of Patna and receives domestic discharge from various points, it becomes heavily polluted with organic pollutants especially near Antaghat, where, monoculture of tubificids was noticed with few insect larvae like Chronomus sp, Psychoda sp etc. Many researchers have been completed on water pollution. Dr. Z. Karim, Dr. Saleemul Haque, Md. Mahiuddin Ahmed, Masud Nabi Khan worked on water pollution. Their findings showed that polluted water may damage living beings partially or folly. They classified pollutants in four classes e.g. a) Pathogens b) Nutritious and biodegradable substances c) Organic agents and d) Toxic substances. Md. Anwarul Islam also worked on it. On the other hand Prof. Jasim Uddin Ahmed worked on arsenic pollution.[17]

\section{Causes of Kharkai water pollution}

\section{Natural and Man-made Causes of Kharkai River}

There are various causes of water pollution of river. These causes can be divided broadly in two divisions, namely: a) Natural causes and b) Man-made causes.

Natural causes: The biodegraded portions of plants and animals mix with water and pollute it. Erosion of river banks caused siltation and this silt sometimes hamper aquatic lives. Many kinds of natural salts and other sub-stances mix with rain water and finally fall in the rivers and ponds.

Man-made causes: The major portion of water pollution of Kharkai river occurred by manmade causes. Industrious wastes, agricultural wastes, domestic wastes, excess etc. are notable manmade pollutants. Water is seriously polluted by 


\section{International Journal of Science and Research (IJSR) \\ ISSN (Online): 2319-7064 \\ Index Copernicus Value (2013): 6.14 | Impact Factor (2015): 6.391}

these pollutants. Water, polluted by such types of pollutants, is very harmful for both human and aquatic lives. Religious and social practices in the Indian Societies in India are glaring example, because they are resulting in damage to the rivers. People worship the rivers as "Goddesses" or "Devi" with great faith in eternity, but these religious activities under the guise of faith, are proving very costly to the rivers, because they involve unmindful and ignorant practices, which cause severe harm to the rivers. The major causes of river pollution also includes burning of dead bodies on the bank of rivers, throwing of un-burnt or half-burnt bodies in the rivers, throwing of carcasses of animals, mass-bathing in rivers and idol immersion in the rivers during the festive seasons

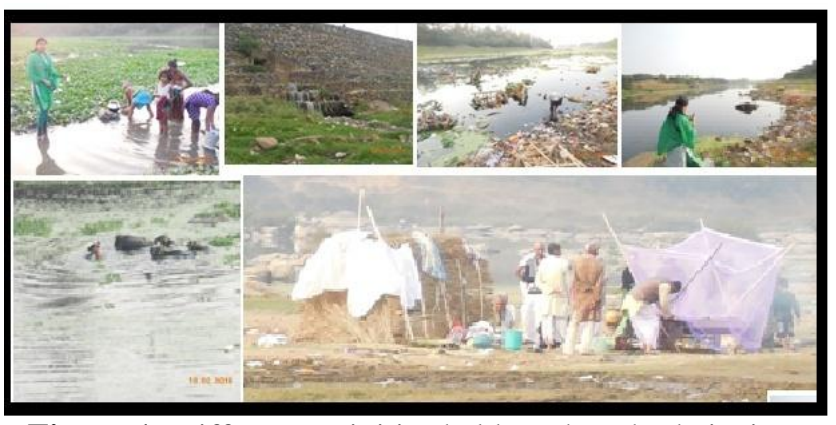

Figure 1: Different activities held on the Kharkai River making it polluted

\section{Sources of pollution Kharkai water pollution}

Untreated wastes of industries, solid wastes of urban and commercial area, wastes of sewerage in municipality, feces of animals, pesticides, fertilizers, radioactive wastes, erosion of lands river banks etc, are the main sources of water pollution. Even the hot water come out of die engine also pollute water. Because hot water help to remove the DO as gaseous oxy-gen. Oil from car wash, industries also pollutes water of Kharkai.

\section{The main pollutants:}

The main water pollutants in Adityapur and Jamshedpur are:

a) Liquid Organic wastes

b) Liquid Inorganic wastes Micro-organisms/germs

c) Nutrient substances

d) Synthetic compounds

e) Inorganic chemicals

f) Silt and sediment

g) Hot water

h) Industrial, Municipal and urban waste

\section{Liquid Inorganic wastes}

Most of the inorganic liquid wastes come from industry, and their dilution in large river waters renders them harm-less. Some inorganic toxic wastes can become concentrated up the food chain to fish. Many of the pollution incidents which have been resulted in largest number of deaths and serious injuries from water pollution have been arisen from human ingestion of fish, or crops contaminated with heavy metals or other inorganic compounds.

\section{Liquid Organic Wastes:}

Wastes when disposed of in water, bacteria and other microorganisms combine with oxygen dissolved in water to break them down, can be termed as "oxygen demanding" wastes. Liquid organic wastes include sewage, many wastes and run-off from rains, floods and storms which picks up organic wastes from land, before flowing into streams, rivers, lakes or seas. As concentration of dissolved oxygen decreases, so fish and aquatic plant life suffer or die. The industrial area in Adityapur is situated with the densely populated regions. There are many hazardous and potentially dangerous polluting industries situated in the cities of Jharkhand. In Adityapur, food processing industries are situated along with chemical and heavy metal processing industries.

Micro-organisms/Germs: With the feces of animals and humans, wastes of sewerage etc. various kinds of bacteria, virus and other organisms spread out in the water bodies and pollute it. Poultry farms and slaughterhouses always supply such kinds of micro-organisms to the water bodies.

Nutrient substances: Domestic substances, excess fertilizers, minerals occurring nitrate are mixing with water. These nutrient substances caused fast growth of unexpected plants, rotting these plants make water offensive taste and odor. Such kind of abnormal growth of aquatic plants is called "eutrofication".

Synthetic compounds: Various cleaning agents soaps, detergents pesticides and other chemical substances are belong to this group Industries also excrete such kind of compounds.

Inorganic chemicals; many metals like lead, zinc, cadmium, mercury, arsenic and their compounds are inorganic pollutants.

Silt and sediment: Soil erosion gives rise silt and sediment in water bodies.

Hot water: Thermal industries use huge amount of cold water to cool their engines from overheating. This hot water is thrown to the nearby water bodies and caused depletion of DO.

\section{Degree of Hazard to Public Health}

Highly toxic materials via ingestion or inhalation are corrosive to skin. These toxics are potential carcinogenic for human. The concentrations of toxics are in excess of what is not welcome and the unabsorbed chemicals are discharged in the effluent, where they are a waste and cause expensive treatment problems. While the Chemical companies in the Federal Republic of Germany, the United States, the United Kingdom, Switzerland, Spain and Italy provide short term training on the application of their chemicals, Whereas there are no provision of providing any assistance how to treat toxic effluents that increasingly contaminate surface and ground water. At present in Adityapur there is no Sewage treatment plant to protect the Kharkai River. Consultants must provide technological transfer and management either on arm's length fee paying basis on assignment or financed by the Agencies. When the local industry was basically a producer of toxic substance, this effluent might have been high in BOD and un-pleasant but particularly dangerous. No one knows how much harm and potential water born diseases will occur to the slum inhabitants. There is no warning from the Government or aid giving agencies or their representatives to aware the Adityapur population. This is 


\section{International Journal of Science and Research (IJSR) \\ ISSN (Online): 2319-7064 \\ Index Copernicus Value (2013): 6.14 | Impact Factor (2015): 6.391}

the vicious circle that the poorest groups are the worst victims of Kharkai river pollution.

\section{Kharkai turns into a toxic dump}

Severe pollution has reduced the river Kharkai into a 'dumping drain' of toxic refuse, threatening number of people living on its banks with serious health hazards and a loss of their livelihoods. That the river is dying is clearly evident from its stench. The highly toxic waters release a 'gas' that starts irritating the nostrils and throat as soon as humans breathe it. Its foul odors can be smelled from as far away as half a several meters. "Sometimes we are unable to sit in our house due to the unbearable stench from the river water," said a people live at the Kharkai river bank. Soon after the floodwater receded and the river wore its lean period look, the pollution instantly increased due to a lack of dispersion. Several hundred industries, topped with a huge volume of untreated sewage from the city, now remain almost stagnant within the river water. The situation is set to continue until a new flow of water rushes in from the upstream, beginning in perhaps another two months. In the meantime, people living along the river are the worst victims of the pollution, which they say is worse than anything they've seen in previous years. Number of villagers bring water from the river Kharkai for their daily uses and for the drinking purpose also. Unable to take a bath or wash clothes for days, many of them have even begun to suffer from various diseases. "We can't use the water of the Kharkai for bathing, washing or cooking," said local people. "For cooking, we use the water collected from faraway places from our house," said local women. Some people said that even for washing the floor or the vessels they have to bring water from relatively less polluted region of the rivers such "Sometimes, when we require more water we are forced to buy tap water at a high price," said a city people.

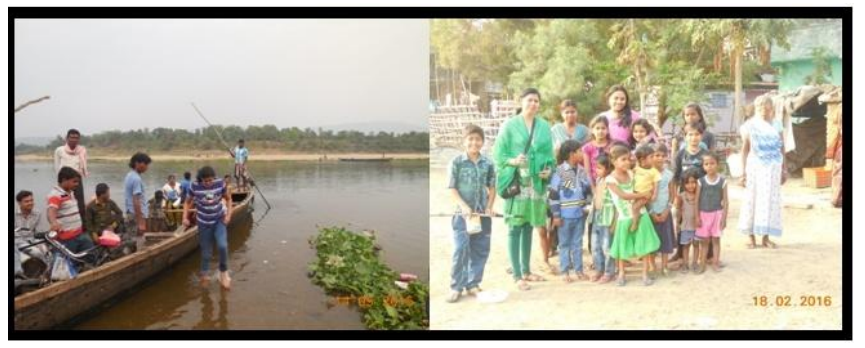

Figure 2: Meet with local people during Sampling

Table 1: Inter-linkage of pressures, state, impacts, and various responses related to water

\begin{tabular}{|c|c|c|c|}
\hline Pressures & State & Impacts & Responses \\
\hline $\begin{array}{l}\text { Pollution } \\
\text { - Industrial effluent } \\
\text { - Fecal Pollution } \\
\text { - Vehicles washing } \\
\text { - Low water flow in the } \\
\text { river system in dry season }\end{array}$ & $\begin{array}{l}\text { - Decreasing inland water } \\
\text { - quality in dry season } \\
\text { - Decreasing coastal water } \\
\text { - quality } \\
\text { - Salinity intrusion in } \\
\text { - surface and groundwater } \\
\text { - Soil salinity increase } \\
\text { - No primary or secondary } \\
\text { - measurement is available } \\
\text { - on discharge quantity }\end{array}$ & $\begin{array}{l}\text { - Pressure on urban water } \\
\text { - source } \\
\text { - Fish fingerling mortality, } \\
\text { - migration and quality of fish } \\
\text { - Degradation of fish habitat } \\
\text { - Yield reduction (soil fertility } \\
\text { loss) } \\
\text { - Increase in risk from } \\
\text { - } \quad \text { waterborne diseases }\end{array}$ & $\begin{array}{l}\text { - Environmental Conserva- } \\
\text { tion Act and Regulation } \\
\text { - Setup environmental } \\
\text { quality standard } \\
\text { - Industrial EIA and } \\
\text { effluent } \\
\text { - treatment plants to reduce } \\
\text { pollutants load } \\
\text { - Polluters pay principle } \\
\text { - National Water Policy: } \\
\text { for water development } \\
\text { projects increase surface } \\
\text { - and ind } \\
\text { water flow in dry season }\end{array}$ \\
\hline $\begin{array}{l}\text { Scarcity (dry season) } \\
\text { - Upstream withdrawal for } \\
\text { consumptive and no } \\
\text { consumptive use } \\
\text { - Low rainfall } \\
\text { - Gradual siltation in river } \\
\text { bed and floodplain } \\
\text { - Flood }\end{array}$ & $\begin{array}{l}\text { Decline river water level } \\
\text { and discharge } \\
\text { - Low water flow } \\
\text { - Shrinking dry season water } \\
\text { area } \\
\text { - Decline/fluctuation of } \\
\text { - groundwater } \\
\text { - Less access to safe } \\
\text { - drinking water }\end{array}$ & $\begin{array}{l}\text { - Decline in aquatic re-sources } \\
\text { - } \text { Naduction } \\
\text { - Increase conflict among } \\
\text { - different users and sectors } \\
\text { - Domestic uses } \\
\text { - Increase pressure on } \\
\text { - groundwater } \\
\text { - Quality of water decline }\end{array}$ & 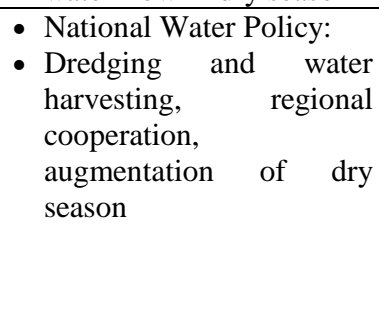 \\
\hline
\end{tabular}

\section{Measuring Parameter:}

Various key parameters and indicators of water quality are monitored. These include physiochemical characteristics of water, like $\mathrm{pH}$, DO, BOD, COD, TSS, SS, total coli forms, heavy metals, turbidity temperature etc.

\section{State of river pollution:}

Many rivers of Jharkhand are polluted. Among them the scenery of Kharkai:

In Jharkhand the Kharkai River is also a polluted one. The most significant source of pollution is appears to be from industries and population. The wastes of industries contain harmful chemicals which. In the dry season The DO level becomes very low and the river becomes very toxic. Table two shows DO of Two different spots of Kharkai River in dry season in 2016.

Table 2: Water quality of Kharkai River at Adityapur

\begin{tabular}{|c|c|c|}
\hline Month & Point & DO (mg/L) \\
\hline January & Under Kharkai Bridge & 3.12 \\
\hline January & $1 \mathrm{Km}$ upstream Kharkai bridge & 8.22 \\
\hline February & Under Kharkai Bridge & 3.91 \\
\hline February & $1 \mathrm{Km}$ upstream Kharkai bridge & 9.32 \\
\hline March & Under Kharkai Bridge & 4.67 \\
\hline March & 1 Km upstream Kharkai bridge & 9.96 \\
\hline April & Under Kharkai Bridge & 5.13 \\
\hline April & $1 \mathrm{Km}$ upstream Kharkai bridge & 10.13 \\
\hline
\end{tabular}




\section{International Journal of Science and Research (IJSR) \\ ISSN (Online): 2319-7064 \\ Index Copernicus Value (2013): 6.14 | Impact Factor (2015): 6.391}

Impacts of pH on:

There is no normal $\mathrm{pH}$ that applies to all fishes. Fish originate in ponds, rivers, lakes, oceans that have different $\mathrm{pH}$ level. But sudden change of $\mathrm{pH}$ can be harmful or even fatal to fishes. Table 3 shows this

Table 3: The Importance of $\mathrm{pH}$ for fish

\begin{tabular}{|c|c|c|}
\hline Min pH & Max pH & Effect \\
\hline 3.8 & 10 & $\begin{array}{c}\text { Fish eggs could be hatched but deformed } \\
\text { young's are often produced }\end{array}$ \\
\hline 4 & 10.1 & $\begin{array}{c}\text { Livable limit for the most resistant fish } \\
\text { species }\end{array}$ \\
\hline 4.1 & 9.5 & Range tolerated by trout \\
\hline 4 & 4.3 & Crops die in 5 days \\
\hline 4.5 & 9 & Trout's eggs and larvae develop normally \\
\hline 4.6 & 9.5 & Limit for perch \\
\hline- & 5 & limit for stickle \\
\hline 5 & 9 & tolerable limit for most fishes \\
\hline- & 8.7 & Upper limit for good fishing water \\
\hline 5.4 & 11.4 & Fish avoid water beyond this limit \\
\hline 6 & 7.3 & optimum (best) range for fish eggs \\
\hline
\end{tabular}

The most significant impact of $\mathrm{pH}$ involves "Synergistic" effect. It involves the combination of two more substances that produces effects greater than their sum. For example, 4 $\mathrm{mg} / \mathrm{L}$ iron would not present a toxic effect at a $\mathrm{pH}$ of $4.8 \mathrm{but}$ as little as $0.9 \mathrm{mg} / \mathrm{L}$ of iron at a $\mathrm{pH}$ of 5.5 can cause fish to die. Excess of pollution leads to the formation of algal blooms .

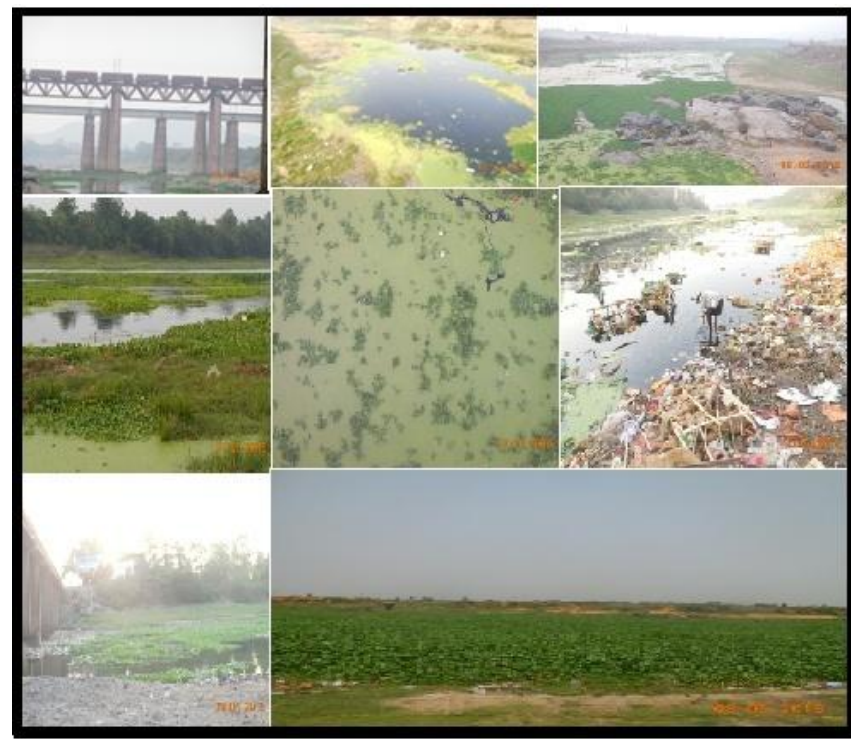

Figure 3: Blooms formation due to polluted river water at different places of River Kharkai near Adityapur

\section{Impacts of trace elements/ions}

Arsenic, lead, mercury, cadmium, chromium, nitrates, nitrites etc. may mix with water directly may be produced from the pollutants. However exceeding limit of this trace elements or ions caused various harm for human and other living beings.
Table 4: Hazards of trace elements or ions

\begin{tabular}{|c|c|}
\hline $\begin{array}{r}\text { Name of } \\
\text { element/ion }\end{array}$ & Impacts \\
\hline Arsenic (As) & $\begin{array}{c}\text { Dermatitis, Muscular paralysis, Damage to liver } \\
\text { and kidney, Loss of hair, Gangrene, Cancer }\end{array}$ \\
\hline Cadmium (Cd) & Kidney damage, Cancer \\
\hline Chromium (Cr) & Skin ulcer, Kidney inflammation, Cancer \\
\hline Lead (Pb) & Neurotoxin, Blood system and brain damage \\
\hline Mercury (Hg) & Nerve damage, Kidney damage \\
\hline Nitrate (NO3) & $\begin{array}{c}\text { Diseases of domestic animals (above 75 ppm ), } \\
\text { Harmful for baby (above 67 ppm ) }\end{array}$ \\
\hline
\end{tabular}

\section{Impacts of germs/micro-organisms}

The people who are living By the Kharkai which is polluted by various germs and micro-organisms are severely suffering from various diseases like cholera, diarrhea, Dysentery etc, often.

\section{Impacts of Silts}

Silt may cover the leaves of aquatic plants and increase the turbidity of water, as a result, sunlight can't reach to the leaves of the plants and photosynthesis reaction is hampered. So, plants can't produce oxygen and food for them. Consequently, ecosystem is hampered.

\section{Analyses of data and information}

The data and information presented here shows the causes, states and Impacts of water pollution of Kharkai. Surface water of Adityapur is polluted by industrial effluents, domestic and sewerage dirt, oil and lube spillage and sediment. Maximum industries excrete toxic substances to water. Some sources spread germs and caused diseases. Excess use of chemicals caused water pollution by supplying nutrient for unexpected plants which finally causes depletion of DO through eutrofication. Again most of the nitrate of urea goes through the soil to the ground water. Silt and sedimentation refrains sun light from passing through water to the aquatic plants. As a result, photosynthesis can't take place. DO is very much essential for aquatic animals. Biochemical db Oxygen Demand (BOD) and chemical Oxygen Demand (COD) rising means substances which consume oxygen from water increases in water bodies. So, higher the BOD and COD mean lower the DO and more hazards for aquatic animals. Chlorinated pesticides are dangerous water pollutants. They affect human nerve accumulating through food chain.

\section{Research findings}

Analyzing the data and information presented in this term paper findings that we got are-

No water is found actually pure. Naturally some substances are mixed with water. Again some natural pollutants removed automatically. Rivers are polluted by both natural and man-made sources like industries and indiscipline activities. Unconsciousness of people is also responsible for water pollution. People should aware about river pollution. Polluted water can do harm to human and aquatic plants directly or indirectly. That is, water pollution affects the ecosystem. Toxic substances directly affect living being through drinking water. Some toxic substances accumulate in the body and then express its contamination. Arsenic pollution is a burning issue in Jharkhand. Maximum people are drinking Kharkai river water directly. Less water flow is 


\section{International Journal of Science and Research (IJSR) \\ ISSN (Online): 2319-7064 \\ Index Copernicus Value (2013): 6.14 | Impact Factor (2015): 6.391}

one of the reasons for toxicity in water, Because of less amount of water flow the concentration of pollutants become high.

\section{Recommendation}

The recommendations in the light of this research work are given below

1) Industries should be located in separate area and code of establishing industries must follow properly.

2) Effluents of industries must be treated and monitored sincerely before throwing it to water body.

3) Modern wastes management methods should be applied. Private sectors may be encouraged for introducing modern recycling process.

4) Urban sewerage system should be developed and the wastes should be treated before dumping it to water body.

5) Rural people should be aware of alternative uses of animal feces.

6) Foods, containing vitamins and nutrients should take for remedial of arsenic contamination.

7) Mass media should come forward in publicity of causes and impacts of water pollution.

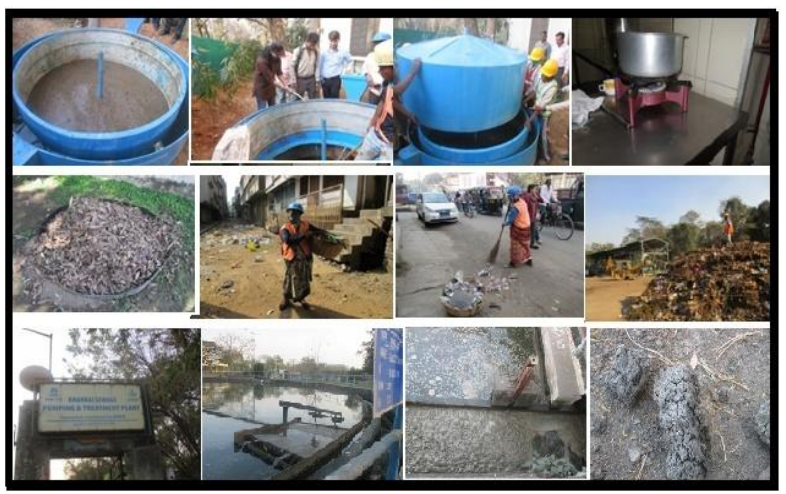

Figure 4: Different waste management systems implemented at Jamshedpur

\section{References}

Journals

[1] Arora H.C., Routh T., Chattopadhyaya S.N., and Sharma V.P.(1974). Survey of sugar mill effluent disposal part II, A comparative study of sugar mill effluent characteristics, India J. Environ. Hlth. 16(3), 233-246 (9)

[2] Bandy, J.T. (1984). Water characteristics. J. Wat. Poll. Cont. Fed. 56(6), 544-548 (10)

[3] Basu A.K., (1966). Studies in effluents from pulp paper mill and its role in bringing the physicochemical changes around several discharge point in the Hoogly Estuary. Indian J. Int. Eng. 46,108-116 (11)

[4] Dakshini, K.M.M. and Soni, J.K. (1979). Water quality of sewage drains entering Yamuna in Delhi. Indian J. Environ. Hlth. 21, 354-360 (13)

[5] Goel P.K. and Trivedi R.K. (1984). Some considerations on sewage disposal to fresh water and resultant effects. Poll. Res. 3, 7-12 (15)

[6] Kothandaraman, V., Thergaonkar, V.P., Koskij, T. and Ganapati, S.V. (1963). Physico chemical and biological aspects of Ahmedabad Sewage. Environ. HIth. 5:356-363 (16)

[7] Matkar, L.S. and Gangotri, M.S. (2002). Physicochemical analysis of sugar industrial effluents. J. Indl. Polln. Cont. 18(2), 139-144 (18)

[8] Prasad, R.R. (1952). Priliminary observations on the temperature gradients and light penetration in the upper 200 feet of water of the Bay of Bengal. Proc. Indian Acad. Sci. 36, 61-69 (19)

[9] Rai H. (1974). Limnological observation on the different rivers and lakes in the Ivory Coast: Hydrobiologia, 44(213), 301-317 (1)

[10] Shukla, B.D., Suresh, C., Tripathy R., Deep Kumari V. and Pande, V.S. (1989). Physico-chemical and biological characteristics of river Ganga from Mirzapur to Ballia. Indian J. Envrion. H1t, 31(3), 218227 (3)

[11] Sivakumar, A.A., Arunadevi, P., Aruchami, M. (2003).Studies on water quality of the river Ambarapalaym, Coimbatore district, Tamil Nadu. Nature Env. Polln. Techno, 2(3), 305- 08 (20)

Book

[12] Shah A.R. (1988). Physico-chemical aspects of pollution in river Jhelum (Kashmir) during 1981-83. Book Ecol. and Pollu. of Indian Rivers. (Ed Trivedi R.K.) Ashish Pub. House New Delhi (1). 163-207 (6)

[13] Gautama, A.C, (1990). Ecology and Pollution of Mountain Water, Ashish Publishing House, NewDelhi, pp 4,. (21)

Chapter in a book

[14] Ciaccia L., (1972). Water and Water Pollution Hand book. Mercel Dekker, Inc. New York. 3, 801- 808 (12)

[15] Rai H. (1974). Limnological observation on the different rivers and lakes in the Ivory Coast: Hydrobiologia, 44(213), 301-317 (1)

Thesis

[16] Sikander, M.; (1987). Ecology of river Ganga in Varanasi with special reference to pollution. Ph.D(Thesis), B.H.U., Varanasi, (4)

Website

[17] www.researchgate.net/Buriganga Pollution:Reasons \& prospect.

\section{Author Profile}

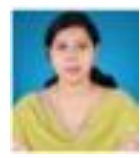

Meenu Verma did M.Sc., M.Ed., M.A. Education. She is Ph.D. Scholar. She is affiliated with Kolhan University, Chaibasa. She has 16 publications in National \& International Conferences and Journals. She has Teaching Experience 02 years

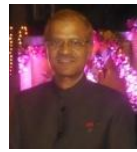

Manoj Ranjan Sinha is M.Sc.,(plant Pathology) Ph.D.(microbiology). He is affiliated with Jamshedpur Cooperative College, Jamshedpur. He is serving as Associate Professor \& HOD, Department of Botany, Jamshedpur Cooperative College, Jamshedpur; A constituent unit of Kolhan University, Chaibasa 